\title{
Affecting Factors Teacher Work Satisfaction
}

\author{
Safrijal $^{1 *}$, Rosmala Dewi ${ }^{2}$, Darwin $^{3}$ \\ ${ }^{1}$ STIKes Cut Nyak Dhien Langsa/Universitas Sains Cut Nyak Dhien \\ ${ }^{2,3}$ Universitas Negeri Medan \\ ${ }^{*}$ Corresponding author: \\ Email: rijal.cnd@gmail.com
}

\begin{abstract}
.
This study aims to determine the factors that effect teacher job satisfaction. In obtaining the data, a quantitsative approach is used with an explanatory coreeelational design because it aims to describe and measure the degree of relationship between variables in causal modeling using part analysis. The results showed that:First, leadership has a direct effect on teacher job satisfaction with a path coefficient of 0.173. Second, self esteem has a direct effect on teacher job satisfaction with a path coefficient of 0.173.
\end{abstract}

Keywords: Leadership, Self Esteem, Job Satisfaction.

\section{INTRODUCTION}

Job satisfaction is an important theory in an organization and will have an impact on success for someone at work. eacher job satisfaction is an important tool in human resource management. Therefore, teacher job satisfaction needs attention in human resource management, which, either directly or indirectly, will affect the quality of education in schools. Teacher job satisfaction can be enjoyed at work, outside of work, and a combination of inside and outside the teacher's job. Teacher satisfaction in work is job satisfaction that is enjoyed at work by getting praise for work results, placement, treatment, equipment, and a good work environment. Teachers who prefer to enjoy job satisfaction at work will prioritize their work rather than remuneration even though remuneration is important.

Basically, job satisfaction is an individual thing, each individual will have different levels of satisfaction according to the value system that applies to him. The more aspects of the job that are in accordance with the desires of the individual, the higher the level of satisfaction that is felt and if job satisfaction is considered, the teacher will work to the extent of his ability to get what is expected in work. Individual teacher job satisfaction is very important, both for the teacher itself, and for schools as educational institutions, with high teacher job satisfaction, it is more likely that teachers 'personal goals and educational institutions' goals to improve the quality of education are more likely to be achieved. A high level of job satisfaction will make the organization more stable, making it easier to achieve its goals. 
Job satisfaction is a positive or pleasing emotion for an individual which is obtained by appraising the job or work experience [1]. Job satisfaction is described as an individual's positive attitude towards his job or refers to a person's positive attitude towards their job, someone with a high level of job satisfaction shows a positive attitude towards their work, while someone who is dissatisfied with their work shows a negative attitude towards their work [2].

Job satisfaction is a very complex factor because it is influenced by various factors, including the leadership of the Principal. Leadership as a process of influencing others to get an effective job and plays a role in generating job satisfaction. The role of the Principal can provide opportunities for teachers to solve problems together, provide direction so that teachers can prioritize the implementation of tasks over other matters and complete their work on time, determine problem solving for problems faced by teachers, and be able to provide examples or demonstrate tasks that are must be done [3] The results show there is an influence of leadership with teacher job satisfaction $[4,5,6]$.

Teacher job satisfaction needs to be paid attention by the principal as a leader, because if the teacher's job satisfaction is high, the teacher will work sincerely, be more active, and willingly optimize all the potential they have for achieving the goals of the school. Teachers as implementers of education in schools who are directly related to students have an important role in improving the quality of education and achieving educational goals. A teacher who has a positive attitude towards his job will carry out his function and position as a teacher and educator in schools with a full sense of responsibility. On the other hand, a teacher who has a negative attitude towards his job, only carries out his function and position as a routine. The teacher has a meaning as someone who has the duty and responsibility to educate and develop the personality of students, both at school and outside of school [7]. Teachers are professional educators with the main task of educating, teaching, guiding, directing, training, assessing, and evaluating students in the formal education pathway [8].

The leadership of the principal plays an important role in efforts to increase teacher job satisfaction. In the teaching and learning process, leadership is a form of activity in life that contains the intention of influencing others to be willing together to go to something that has been determined based on educational goals. The principal is the highest ranking holder in the management of a school. Arrangements made by a school principal are related to the work of staff both as educators and non-educators; legal regulations and curriculum as well as facilities and infrastructure that must be provided by schools according to the demands of parents and students as users of educational services. The principal is the center of all school improvement initiatives in the teaching and learning process, and as such, the principal is the agent of change for school success, and is expected to explore and wisely utilize resources for continuous improvement in school organizational performance [9]. The principal is the answer to a development and improvement of school academic performance in general, in which 
the effective principal creates an environment that stimulates enthusiasm for learning [10]. Thus, it shows that the principal's main job is to create an atmosphere that encourages productivity, effective teaching and learning.

In addition to principal leadership, teacher job satisfaction can also be created when the teacher has good self-esteem (self-esteem). The higher the self-esteem of a teacher in carrying out his duties, the better his job satisfaction. Self esteem is a selfworth belief based on overall self-evaluation. A teacher who has strong self esteem will be able to build better relationships with others, be polite and make himself a successful person. Conversely, teachers who have weak self-esteem will have a negative self-image and bad self-concept. That teachers with a high level of selfesteem will have better job satisfaction than teachers with a low level of self-esteem. The results showed that there was a significant relationship between job satisfaction and teacher self-esteem $[11,12]$.

Factors that affect job satisfaction are: (1) Physiological, the need to drink, eat, shelter and be free from pain; (2) Self-esteem, the need for self-esteem and respect from others; (3) Self-actualization, the need to fulfill oneself by maximizing abilities, expertise and potential; (4) Safety and security, the need for freedom from threats, that is, being safe from the threat of an incident or the environment; (5) A sense of belonging (belongingness), social and love needs for friends, affiliation, interaction and love [13]. By having high self-esteem, individuals can develop themselves so that they can feel life satisfaction. Someone who feels life satisfaction will create welfare that causes positive affect or feelings and reduces affect or negative feelings.

Self esteem refers to how a person subjectively assesses himself, his abilities and potential. A person who is positive for his / her potential and self-development is believed to have positive self-esteem. With the ability to see himself positively, in the future it will be very helpful in striving for his own career success. Not only that, selfesteem also greatly determines a person's confidence in the abilities he has.

Individuals with high self-esteem believe that they have the necessary character and traits. There are three possibilities for individuals with self-esteem, namely: (1) having a higher level of job satisfaction and motivation, (2) showing a deeper level in various tasks and fields, and (3) being more successful in identifying and getting a suitable job. One of the reasons for the low job satisfaction of teachers is the lack of self-esteem, which is one aspect of personality that has an important role and has a major influence on individual attitudes and behavior. Self Esteem is an awareness of how much value is given to oneself. So self-esteem can affect teacher work motivation and job satisfaction [14].

Based on the results of a preliminary study conducted by researchers at the State Elementary School in Langsa City, it was found that a phenomenon that occurs in the field shows that teacher job satisfaction is very low where symptoms such as absenteeism, laziness to work, lots of complaints from teachers, lack of interest and 
enthusiasm in teaching and indiscipline occur. in teaching. This will have an impact on the quality of education in schools. This work dissatisfaction is also due to the absence of additional income other than the salary from the profession as a teacher and the salary that is deemed not in accordance with the workload received. From the findings above it can be concluded that teacher job satisfaction is still not good, this is because the principal's leadership has not performed its function properly, besides that the principal never invites teachers to jointly decide a policy, then very rarely helps teachers in solving problems In his face, the teacher also complained that the principal lacked empathy for his complaints. This research aims to provide an overview of the factors that affect teacher performance.

\section{METHODS}

This research method is included in explanatory correlational research because it aims to describe and measure the degree of relationship between variables in causal modeling using path analysis. The population in this study were all State Elementary School teachers in Langsa City, namely 613 people spread across 57 public schools. The sampling technique used random sampling techniques, and resulted in a sample of 242 people. The data analysis techniques used in this study include descriptive analysis, analysis requirements test, and hypothesis testing.

\section{RESULT AND DISCUSSION}

Data descriptions that will be presented in this section include leadership variable data $\left(\mathrm{X}_{1}\right)$, Self Esteem $\left(\mathrm{X}_{2}\right)$, and Job Satisfaction $\left(\mathrm{X}_{3}\right)$.

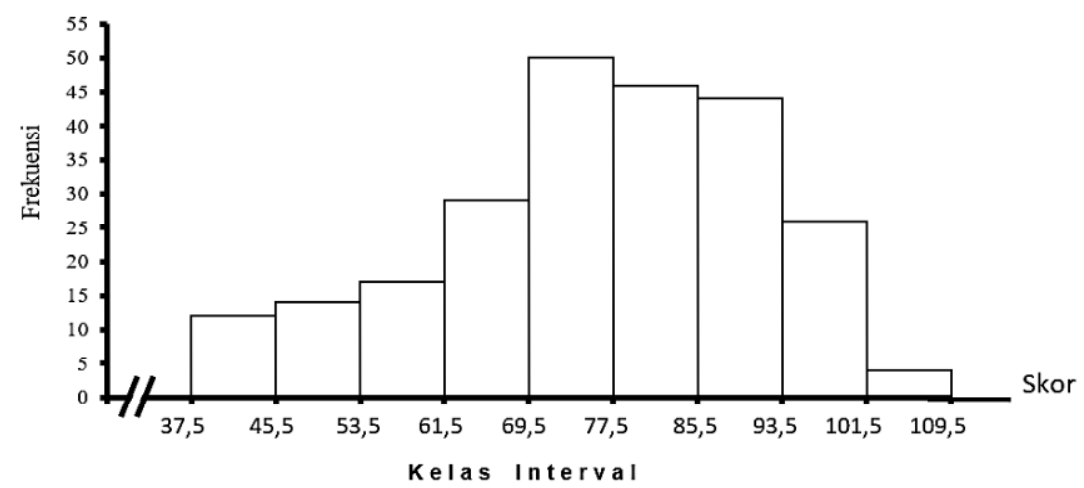

Figure 1. Histogram of Leadership Score $\left(\mathrm{X}_{1}\right)$

Based on the data in Figure 1 above, it can be seen that the score of leadership measurement results is dominated by the 70-77 interval class as many as 50 people or $20.66 \%$. The smallest percentage value is in the interval class $102-109$, which is 4 people or $1.65 \%$. The average score of 75.94 lies in the interval $70-77$ as much as $20.66 \%$ ( 50 respondents). A total of $29.75 \%$ ( 72 respondents) were below the average, and $49.59 \%$ (120 respondents) were above the average. 


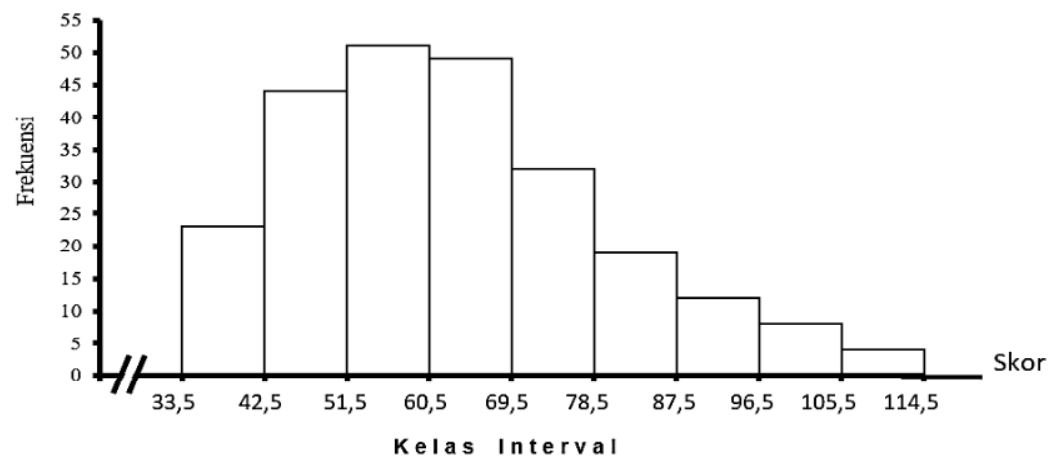

Figure 2.Histogram of Self Esteem Score $\left(\mathrm{X}_{2}\right)$

Based on the data in Figure 2 above, it can be seen that the score of the results of measuring self-esteem is dominated by the 52 - 60 interval class as many as 51 people or $21.07 \%$. The smallest percentage value is in the interval class $106-114$, which is 4 people or $1.65 \%$. The average score of 62.71 lies in the interval $61-69$ as much as $20.25 \%$ (49 respondents). A total of $48.76 \%$ (118 respondents) were below the average, and $30.99 \%$ ( 75 respondents) were above the average.

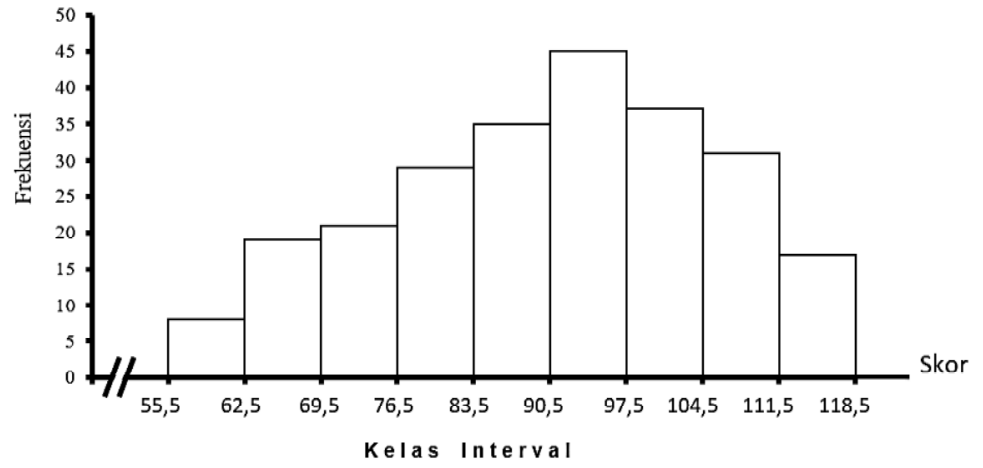

Figure 3.Histogram of Job Satisfaction Score $\left(\mathrm{X}_{3}\right)$

Based on the data in Figure 3. above, it can be seen that the score of the measurement results of job satisfaction is dominated by the class interval $91-97$ with 45 people or $18.59 \%$. The smallest percentage value is in the $56-62$ interval class, which is 8 people or $3.31 \%$. The average score of 90.49 lies in the interval $84-90$ as much as $14.46 \%$ (35 respondents). A total of $31.82 \%$ ( 77 respondents).

The results of further analysis of the average score of indicators on the leadership variable indicate that the Directive (directing) indicator is 2.69; Supportive (support) of 2.91; and Fasilitative (makes it easy) by 2.62. So the dominant indicator in shaping leadership is supportive, and the weakest indicator is facilitative. In improving the leadership of the principal of SD Negeri Kota Langsa, the indicators of facilitative (facilitating) and directive (directing) should receive serious attention, because this indicator is the weakest indicator of leadership. 
The results of the analysis of the average score of indicators further on the selfesteem variable showed that the indicators of self-assessment were 2.27; life assessment of 2.10; and relationships with others at 1.96. So the dominant indicator that forms self-esteem is self-assessment, and the weakest indicator is relationships with other people. In increasing the self-esteem of teachers of SD Negeri Kota Langsa, the indicators of assessing life and relationships with other people must receive attention, because this indicator is the weakest indicator of self-esteem.

While the results of the analysis of the average score of indicators further on the teacher job satisfaction variable showed that the supervisory indicator was 3.06; coworkers 2.91; working conditions of 2.74; and the work itself is 2.85 . So the dominant indicator for job satisfaction is supervision, and the weakest indicator is working conditions. To improve the job satisfaction of Langsa City Elementary School teachers, indicators of working conditions must receive serious attention in order to increase job satisfaction.

Leadership has a direct effect on the Job Satisfaction of SD Negeri Langsa City Teachers, meaning that if the principal's leadership is strong, job satisfaction will increase. This is obtained based on hypothesis testing with a path coefficient of $\rho 31=$ 0.173 and $t=3.088$ with a significance level of 0.002 (the hypothesis is accepted if the significance level is $<0.050$ ), so that the direct effect of leadership on job satisfaction is $17.3 \%$.

The findings of this study are in line with the opinion that job satisfaction is influenced by team mechanisms including leadership behavior and style, leadership power and influence including supervision, team processes, and team characteristics [15]. The findings of this study also support the opinion that employee job satisfaction is influenced by the following factors: (1) fair and proper remuneration, (2) proper placement according to expertise, (3) lightness of work; 4) work atmosphere and environment, (5) equipment that supports the implementation of work, (6) leadership attitudes in leadership, and (7) monotonous or not work characteristics [16]. The findings of this study are in line with the results of research which show that there is an influence of leadership on teacher job satisfaction $[4,5,6]$.

Teacher job satisfaction needs to be paid attention by the principal as a leader, because if the teacher's job satisfaction is high, then the teacher will work sincerely, be more active, and willingly optimize all the potential they have to achieve the goals of the school. The leadership of the principal who is strong in directive, supportive, and facilitative for teachers will make teachers more satisfied in carrying out their duties professionally in accordance with their competence to educate the nation's children to become generations of character and quality.

The need for a sense of job satisfaction for teachers is very important, because a sense of satisfaction in a teacher can make him more enthusiastic in carrying out his duties so that school success is easier to achieve. To foster high morale, good leadership from the principal is needed. The existence of good cooperation from the 
principal makes the teacher feel valued and does not feel awkward in expressing opinions when making school planning.

Self-esteem has a direct effect on Job Satisfaction of Langsa City Elementary School Teachers, meaning that if self-esteem is high, job satisfaction will increase. This was obtained based on hypothesis testing with a path coefficient of $\rho 32=0.173$ and $t=3.136$ with a significance level of 0.002 (the hypothesis is accepted if the significance level is $<0.050$ ), so that the direct effect of self-esteem on job satisfaction is $17.3 \%$.

The findings of this study are in line with the opinion stating that job satisfaction factors are: (1) Physiological, the need to drink, eat, shelter and be free from pain; (2) Self-esteem, the need for self-esteem and respect from others; (3) Self-actualization, the need to fulfill oneself by maximizing abilities, expertise and potential; (4) Safety and security, the need for freedom from threats, that is, being safe from the threat of an incident or the environment; (5) A sense of belonging (belongingness), social and love needs for friends, affiliation, interaction and love $[4,5,6]$.

The findings of this study are also in line with the opinion that individuals with high self-esteem believe that they have the required characters and traits. There are three possibilities for individuals with self-esteem, namely: (1) having a higher level of job satisfaction and motivation, (2) showing a deeper level in various tasks and fields, and (3) being more successful in identifying and getting a suitable job. [4,5,6]. The findings of this study are in line with the results of the study which showed a significant relationship between job satisfaction and teacher self-esteem [11, 12].

High self-esteem allows individuals to develop themselves so that they can feel life satisfaction. Someone who feels life satisfaction will create welfare that causes positive effects or feelings and reduces the effects of negative feelings. A teacher who has strong self esteem will be able to build better relationships with others, be polite and make himself a successful person. Conversely, teachers who have weak selfesteem will have a negative self-image and bad self-concept. That teachers with a high level of self-esteem will have better job satisfaction than teachers with a low level of self-esteem.

\section{CONCLUSION}

Leadership has a direct effect on job satisfaction with a path coefficient value of 0.173. The most influential leadership indicator is supportive. In other words, the stronger the principal's leadership in providing support to teachers, the higher the teacher's job satisfaction. Self-esteem has a direct effect on job satisfaction with a path coefficient of 0.173 . The indicator of self-esteem that has the greatest influence is selfassessment. In other words, the better the self-assessment, the higher the job satisfaction of Public Elementary School teachers in Langsa City. 
International Journal Of Science, Technology \& Management

\section{ACKNOWLEDGMENTS}

The authors are grateful to the head of the Langsa City Education and Culture Office, teachers and principals of the Langsa City Public Elementary School for supporting this research.

\section{REFERENCES}

[1] Luthans, F. Organizational Behavior. New York: Irwin McGraw-Hill Int. Ed. 1998.

[2] Robbins, Stephen P. Timothy A. Judge. Organizational Behavior, 13 Th Edition. Pearson International Edition. Prentice hall. USA. 2009.

[3] Bass, B.M., B.J. Avolio. D.I. Jung. Y. Berson. Predicting unit performance by assessing transformational and transactional leadership. Journal of Applied Psychology, 88:2, 2003, pp 207-218.

[4] Nyenyembe, Fabian W. Maslowski, Ralf; Nimrod, Beatrice S. Peter, Levina. (2016). Leadership Styles and Teachers' Job Satisfaction in Tanzanian Public Secondary Schools. Universal Journal of Educational Research, 2016. 4:5, pp 980-988.

[5] Huang, Hui. Hashem, Salarzadeh, J. Noor, A. Ismai.. Che W. Jasimahbt W. M. Radzi. (2013). Principal's Leadership Style and Teacher Job Satisfaction: A Case Study. Journal Interdisciplinary of Contemporary Research in Busines, 2013, 5:4, pp 175-184.

[6] Carit, Yusuf. (2009). The Effects of Servant Leadership Behaviours of School Principals on Teachers' Job Satisfaction. Jornal Educational Management Administration \& Leadership, 2009. 37:5, pp 600-623.

[7] Surya, M. Aspirasi Peningkatan Kemampuan Profesional dan Kesejahteraan Guru. Jurnal Pendidikan dan Kebudayaan. Jakarta: Balitbang Depdiknas.

2000

[8] Danim, Sudarwan. Profesionalisme dan Etika Profesi Guru. Bandung: Alfabeta. 2013

[9] Cunningham, W.G. dan Cordeiro, P. A. Educational Leadership A ProblemBased Approach. Third Edition. Boston: Pearson. 2006

[10] Hurley, J. C. The Principalship: Less may be more. Education Week. 2001

[11] Ghafari, Hosseini. and Masoumeh, Samii. The relationship between job satisfaction and self-esteem in teachers: A case study in Aliabad University. European Online Journal of Natural and Social Sciences, 2013, 2:3, pp 1702-1705.

[12] Esther, K. Mocheche. Joseph, Bosire. Pamela, Raburu. (2017). Influence of Self-Esteem on Job Satisfaction of Secondary School Teachers in Kenya. International Journal of Advanced and Multidisciplinary Social Scienc, 2017, 3:2, pp 29-39.

[13] Saydam, Gouzali. Managemen Sumber Daya Manusia (Human Resources Managemen) : Suatu Pendekatan Mikro. Jakarta : PT. Gunung Agung.2005..

[14] Baron dan Greenberg. Behavior in Organizations. 10thed. NewYork:Mc-Graw Hill. 1990.

[15] Colquitt, Jason A, Jeffery A Lepine, Mechael J. Wesson. Organizational Behavior. New York : Mc Graw Hill. 2009.

[16] Hasibuan, Malayu SP. Organisasi dan Motivasi, Jakarta: Bumi Aksara. 2006. 